\title{
Regulatory T-Cells Support Stem Cell Therapy in Safe Minimization of Immunosuppression in Living Donor Renal Transplantation
}

\author{
Hargovind Trivedi* ${ }^{1 *}$ Aruna Vanikar², Himanshu Patel ${ }^{1}$, Vivek Kute ${ }^{1}$ and Shruti Dave ${ }^{3}$ \\ ${ }^{1}$ Department of Nephrology, Transplantation Medicine and Immunology, G. R. Doshi and K. M. Mehta Institute of Kidney Diseases \& Research Centre \\ [IKDRC],Ahmedabad, Gujarat, India \\ ${ }^{2}$ Department of Pathology, Laboratory Medicine, Transfusion Services, Immunohematology, G. R. Doshi and K. M. Mehta Institute of Kidney Diseases \& Research Centre \\ [IKDRC],Ahmedabad, Gujarat, India \\ ${ }^{3}$ Senior Research Officer, Stem Cell lab, Transplantation Biology Research Centre, G. R. Doshi and K. M. Mehta Institute of Kidney Diseases \& Research Centre \\ [IKDRC],Ahmedabad, Gujarat, India
}

\begin{abstract}
Background: Stem cell therapy (SCT) has encouraging results in tolerance induction in living-donor renal transplantation (LDRT). T-regulatory cells [CD4+CD25highCD127neg/low] promote tolerogenicity. We report initial experience of LDRT using SCT with Tregs.

Material and methods: In this prospective study of demographically well-balanced 3 groups of 30 LDRT patients each, group-1 underwent donor hematopoietic stem cell (HSC) and adipose-tissue-derived mesenchymal stem cell (AD-MSC) infusion in thymic and portal circulation under non-myeloablative conditioning pre-transplant, and Treg infusion posttransplant, group-2 received SCT alone, and group-3 were transplanted with standard triple immunosuppression. Tregs were derived from co-cultured donor AD-MSC and recipient peripheral mononuclear cells. Maintenance immunosuppression was low dose Tacrolimus + prednisone in groups-1 and 2.

Results: Mean infused CD34+ (N x106/kgBW) were 2.7 in group-1, 2.2 in group-2, ADMSC (N x104/kgBW), 1.37 in group-1 and 1.34 in group-2, and Tregs ( $\mathrm{N} \times 104 / \mathrm{kgBW})$ were 2.21. There were no untoward effects of SCT. Over mean follow-up of 19.34 months in group-1 and 20.6 months in group-2 there was $100 \%$ patient + graft survival. In group-3 over a mean follow-up of 20.55 months, there was $100 \%$ patient survival and $93.3 \%$ graft survival. Their mean serum creatinine $(\mathrm{mg} / \mathrm{dL})$ was $1.35,1.4$ and 1.3 respectively. There were 2 acute rejection episodes in group-1, 5 in group-2 and 7 in group-3, and 1 chronic rejection in group-3. Severity was more in group-3. Tregs in periphery were $3.63 \%$ in group $-1,3 \%$ in group-2 and $1.9 \%$ in group-3.
\end{abstract}

Conclusion: Tregs support SCT in safe minimization of immunosuppression in LDRT.

Keywords: Mesenchymal stem cells; T-Regulatory cells; Stem cells; Renal transplantation; Immunomodulation

\section{Introduction}

Transplantation is well accepted therapy for end organ failure. However it has its own disadvantages in the form of life-long immunosuppression to prevent rejection of the grafted organ. It is a well-known fact that graft survival improves significantly with better HLA-matched donor. However it is not possible to get a good matched kidney for all the patients. In addition, even with good matched organs the patients are kept on standard maintenance immunosuppression universally. Attempts to minimize immunosuppression are going on at different centres with some success [1-5]. We have been using stem cell therapy (SCT) for safe and effective minimization of immunosuppression in living donor renal transplantation (LDRT) [5]. Recently T-regulatory cells (T-regs) $\left(\mathrm{CD} 4^{+} \mathrm{CD} 25^{\text {hi }}\right.$ FoxP3 $\left.^{+}\right)$, a sub-population of $\mathrm{T}$ lymphocytes have been identified for their immumodulatory role in diseases and transplantation. Tregs were formerly known as natural suppressor cells and are involved in shutting down immune responses after successfully eliminating invading organisms. Absence of Tregs was found to be associated with autoimmune disorders [6]. Studies were carried out in transplantation to correlate the levels of Tregs with graft function status [7-9]. T-regs are believed to be associated with sustained tolerance in solid organ transplantation. However there is no report of in vitro generation of T-regs and then using them in vivo. This study aims to present our initial experience of infusing in vitro generated T-regulatory cells (T-regs) in LDRT.

\section{Material and Methods}

\section{Study design}

This was a prospective open-labeled, non-blinded randomized three-armed single center clinical trial of LDRT using our tolerance induction protocol (TIP) with infusion of donor-derived stem cells (SC) and T-regs in group-1, SC in group-2 and no cell therapy in group-3. Patients were recruited between 2012 and 2013 into the protocols by explaining in detail all the procedures, risks, and possible benefits to each prospective allograft recipient and obtaining his/her written informed consent. Study design and consent forms were approved by the Institutional Review Board (IC-SCRT No: 3/12).

*Corresponding author: Hargovind Trivedi, Department of Nephrology, Transplantation Medicine and Immunology, G. R. Doshi and K. M. Mehta Institute of Kidney Diseases \& Research Centre [IKDRC], Ahmedabad, Gujarat, India, Tel: 91792268 7043; Fax: 009179226854 54; E-mail: ikdrcad1@sancharnet.in

Received May 30, 2014; Accepted October 25, 2014; Published November 15 , 2014

Citation: Trivedi H, Vanikar A, Patel H, Kute V, Dave S (2014) Regulatory T-Cells Support Stem Cell Therapy in Safe Minimization of Immunosuppression in Living Donor Renal Transplantation. J Stem Cell Res Ther 4: 240. doi:10.4172/21577633.1000240

Copyright: @ 2014 Trivedi $\mathrm{H}$, et al. This is an open-access article distributed under the terms of the Creative Commons Attribution License, which permits unrestricted use, distribution, and reproduction in any medium, provided the original author and source are credited. 


\section{Protocol for group-1}

Patients were subjected to lymphocyte cross-match (LCM), flow-cross-match (FCM) with T and B-cells and single antigen (SA) on day-0 followed by subtotal lymphoid irradiation (STLI) of 200 centigray for 5 days to create space. Cultured bone marrow (CBM) derived hematopoietic stem cells (HSC) and adipose tissue derived mesenchymal stem cells (AD-MSC) generated from kidney donors were administered in the recipient's thymus and portal circulation on day-10, and peripheral blood stem cells (PBSC) obtained from leucopheresed donors were infused in periphery. Repeat LCM, FCM and SA were carried out on day-16. If immunologically favorable, the patients were transplanted on day-18 under cover of rabbit antithymocyte globulin (rATG), $1.5 \mathrm{mg} / \mathrm{kg}$ body weight (BW). Methylprednisone, $500 \mathrm{mg}$ intravenously (IV) was given on $17^{\text {th, }}$ $18^{\text {th }}$ and $19^{\text {th }}$ day. Immediate posttransplant immunosuppression consisted of Tacrolimus, $0.06 \mathrm{mg} / \mathrm{kgBW}$, and prednisone, $20 \mathrm{mg} /$ day. Bortezomib, $1.3 \mathrm{mg} / \mathrm{m}^{2}$ subcutaneously and methylprednisone, $125 \mathrm{mg}$ IV were administered every third day for a total of 4 doses beginning on day 20. In vitro generated T-regs were infused peripherally 1 month posttransplant (Figure 1).

\section{Protocol for group-2 was same as for group-1 except T-regs}

Group-3 patients were not subjected to SCT. They underwent LDRT after LCM, FCM and SA under the cover of methylprednisone and $\mathrm{rATG}$ (as in groups 1 and 2).

\section{Immune status monitoring}

LCM was performed as per American Society of Histocompatibility and Immunogenetics (ASHI) guidelines using CDCC technique, FCM for T and B-cells was performed by FACscan [Beckton Dickinson (BD) Sciences, USA], and SA was performed using luminex platform. The tests were considered as negative if antihuman globulin (AHG) was $<20 \%$, T and B-cell FCM $<50$ and 100 median channel shift (MCS) respectively, and donor specific antibodies (DSA) had mean fluorescent intensity (MFI) $<2000$.

\section{Chimerism}

A subset of patients with cross-gender donors was subjected to study peripheral blood lympho-hemopoietic chimerism at 1 month and 12 months posttransplant. Peripheral blood $(2.5 \mathrm{~mL}$ in sodium EDTA) was collected, and red cells were lysed using RBC lysis buffer following spinning with phosphate buffered saline at $4-10^{\circ} \mathrm{C}$ for 10 minutes. The lysed cell button was subjected to cytospin, slides were stained with Giemsa stain, de-stained for XX/XY probes (Vysis probesSkyvision Cytogenetics Workstation, Germany) and observed under immunofluorescent microscope.

\section{Stem cell generation and infusion}

HSC, AD-MSC and PBSC were generated as per our previous protocols [5]. For HSC, $100 \mathrm{ml}$ of BM was aspirated from posterior superior iliac crest of donors on day 3 under local anesthesia after cytokine stimulation using GM-CSF, $300 \mu \mathrm{g}$ twice a day for 2 days. It was collected in Dulbecco's Modified Eagle's medium (MEM) with high glucose, essential amino acids, $20 \%$ human albumin, growth factors and antibiotics. The medium was replenished every other day till 10 days. On $10^{\text {th }}$ day, the supernatant was removed and cultured marrow was mixed with AD-MSC after testing its viability, sterility and quantification. The adipose tissue resected from donor's abdominal pad of fat on day 1 under local anesthesia was collected in medium containing alpha MEM, 20\% human albumin, appropriate antibiotics and minced into tiny pieces. Then it was transferred in to medium containing collagenase type 1 for digestion at $37^{\circ} \mathrm{C}$ for 1 hour on a locally designed shaker of Petri dishes (35-40 RPM). The contents of the medium processed after centrifugation at 780 RPM for 8 minutes and then the supernatant and pellets were separately cultured in medium of the same composition in $100 \mathrm{~cm}^{2}$ and $25 \mathrm{~cm}^{2}$ dishes (Sarsted), respectively, at $37^{\circ} \mathrm{C}$ with $5 \% \mathrm{CO}_{2}$ for 10 days. The medium

\section{AHMEDABAD TOLERANCE INDUCTION PROTOCOL}

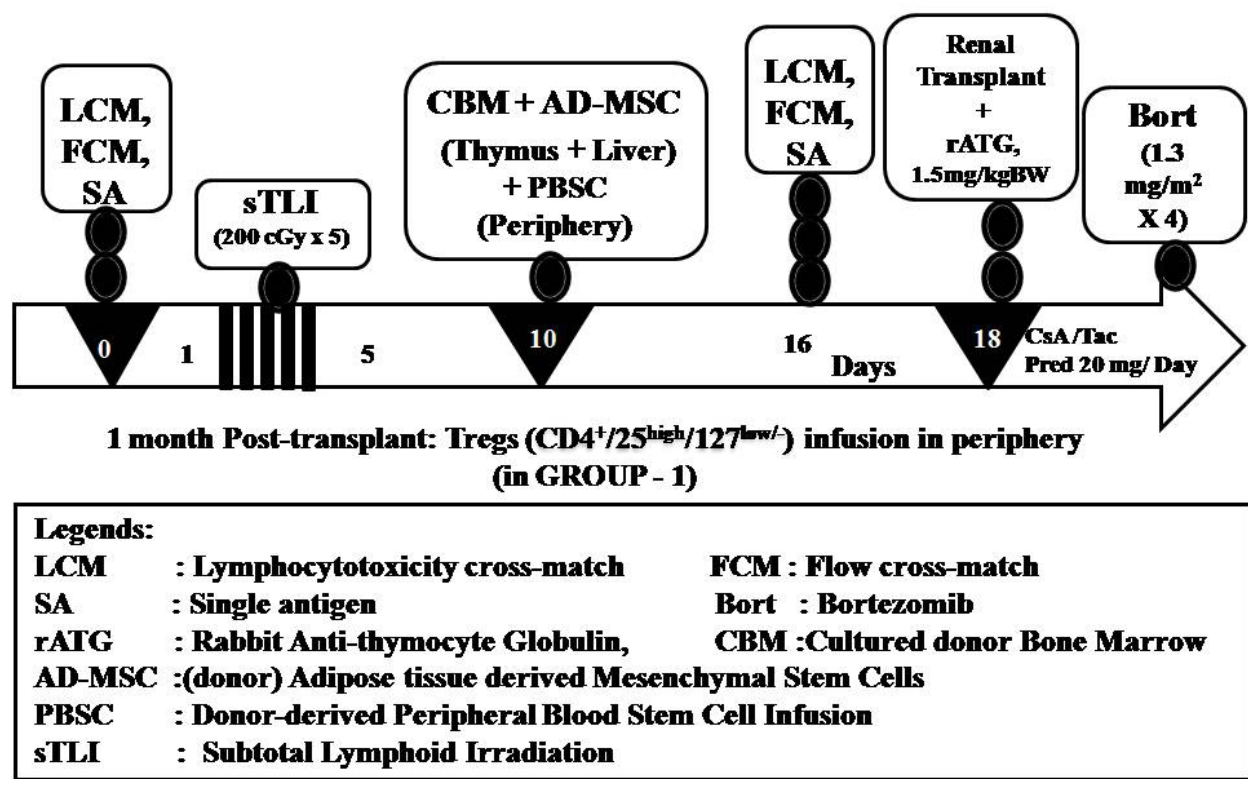

Figure 1: Tolerance induction protocol for group-1. 
was replenished on alternate days and at the end of 10 days the cells were harvested by trypsinization. The collected cells were subjected to flow cytometric analysis. CD45 (perCP) negative and CD90 (PE) positive events were counted before the cells were mixed with cultured $\mathrm{BM}$ for portal infusion. Infusion of HSC and AD-MSC was carried out under $\mathrm{C}$-arm guidance through femoral artery catheterization. Three $\mathrm{ml} \mathrm{SC}$ were infused in thymus and remaining in portal circulation. PBSC were collected from leucopheresed cytokine stimulated donors using GM-SF, 300 microgram subcutaneously, twice a day for 2 days before peripheral infusion.

\section{T-reg generation, characterization and infusion}

Ten gram adipose tissue was resected from donor abdominal pad of fat on $10^{\text {th }}$ posttransplant day and processed for AD-MSC generation by similar methodology described above [5]. On $20^{\text {th }}$ posttransplant day peripheral blood mononuclear cells (PBMC) were isolated from $50 \mathrm{ml}$ blood collected from antecubital vein of recipients. It was layered on Histoprep-cell separation medium (Germany), centrifuged (at 2000 RPM X 18 minutes) and white ring of mononuclear cells was collected. PBMC were divided into two parts; one treated as responder PBMC
(R.PBMC) and second part subjected for irradiation (7 Gray) was treated as stimulator PBMC (S.PBMC). R.PBMC and S.PBMC were cocultured with AD-MSC in RPMI 1480 medium supplemented with IL-2 $(500 \mathrm{U} / \mathrm{ml})$ (In vitrogen, Germany) for 9 days. On $30^{\text {th }}$ posttransplant day, Tregs were isolated, checked for sterility, viability and analysed for characterization followed by infusion into their thymus. Figure 2 depicts T-reg generation and characterization.

\section{Post transplant monitoring}

All patients were monitored initially in-house for 10-15 days postransplant every day and then in the same outpatient clinic twice a week for the first 1 month, weekly for the next 2 months, fortnightly for $4^{\text {th }}$ month, monthly for $5^{\text {th }}$ and $6^{\text {th }}$ month, every 2 months for next 6 months and 3 monthly thereafter. However in event of fever, gastrointestinal disturbance or any other complaints or suspicion of graft dysfunction they were called immediately to the clinic. Posttransplant monitoring for all groups included complete blood counts, urine examination and serum creatinine (SCr) to determine the graft function status, and rule out infections including graft versus host disease (GVHD) / BM suppression in groups-1 and 2. Tregs were tested

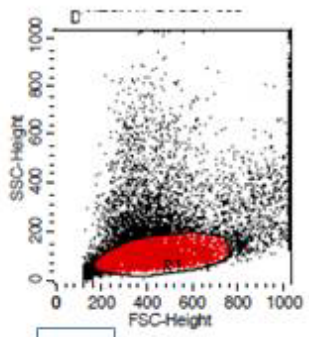

$\mathbf{2 a}$

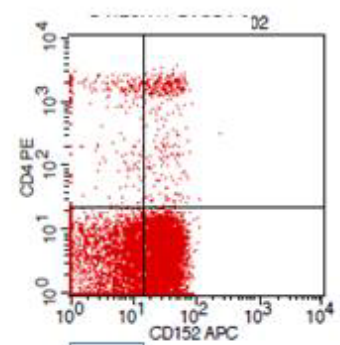

2c

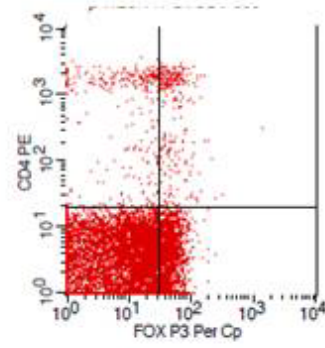

2e
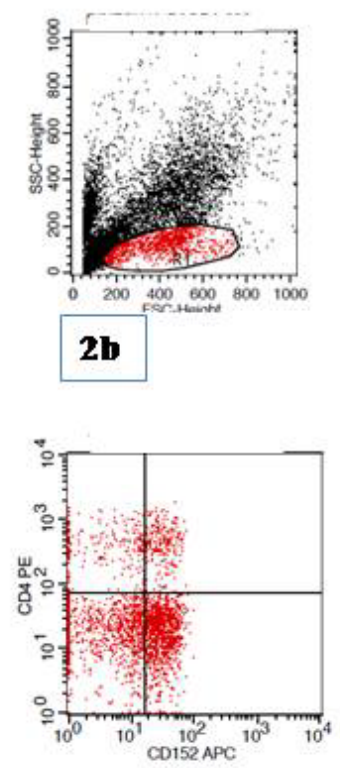

2d

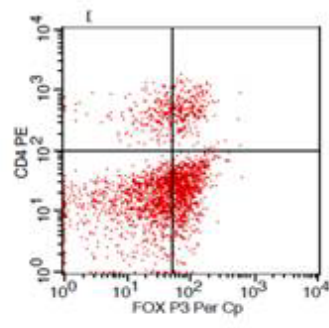

$2 \mathbf{f}$
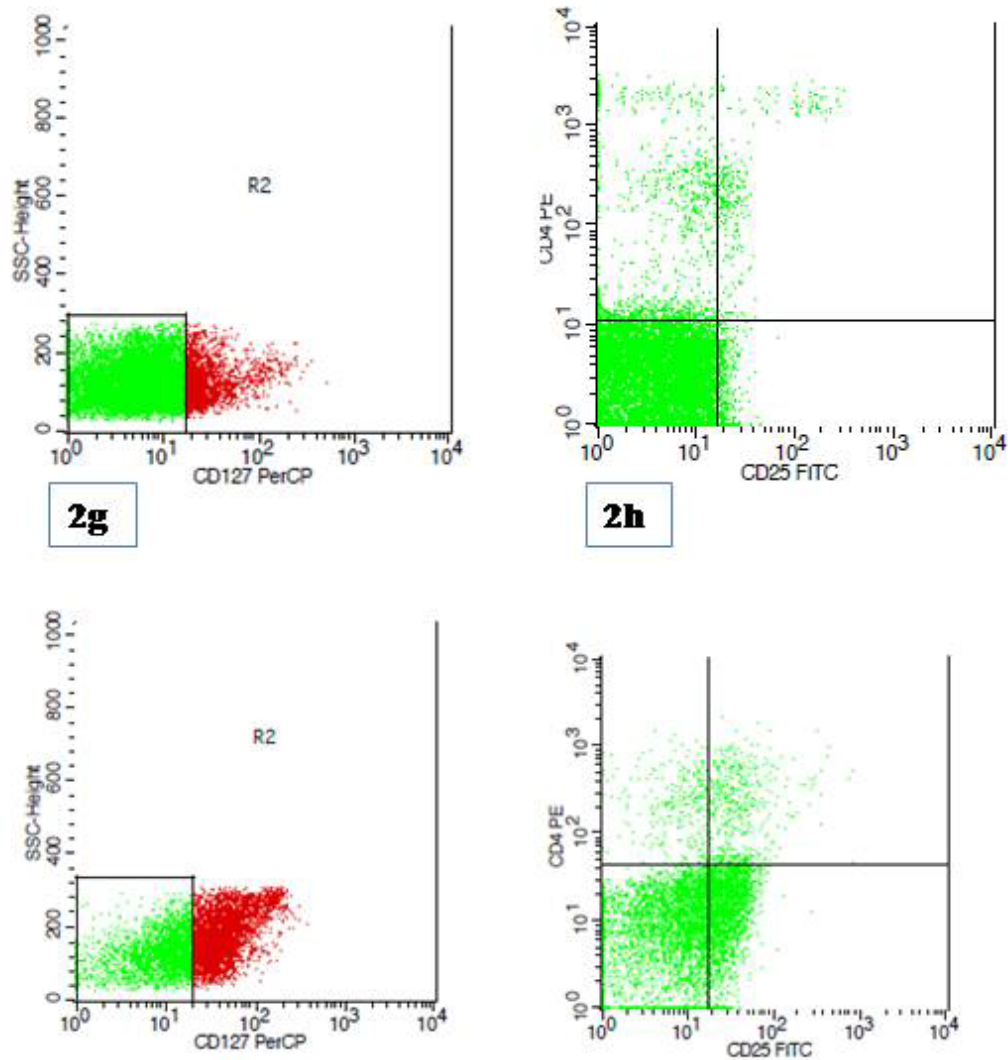

$\mathbf{2 i}$

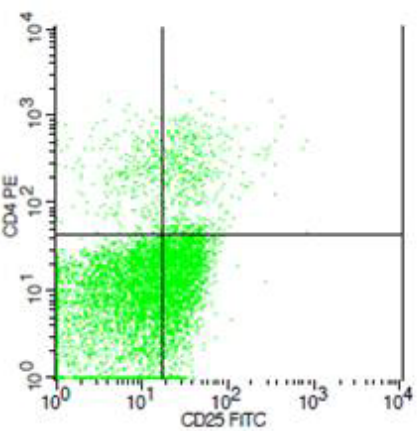

2j

Figure 2: Flow cytometric analysis showing T-regulatory cell characterization and generation. On left top, figure 2a with side scatter on $Y$ axis and forward scatter on X-axis depicted by gated cluster of mononuclear cells from immunosuppressed recipients' peripheral blood mononuclear cells and on right, figure $2 \mathrm{~b}$, the same depicted after in vitro generation. In figures $2 \mathrm{c}$ and $2 \mathrm{~d}, \mathrm{CD} 4+\mathrm{CD} 152+$ cells depicted before and after in vitro generation respectively. In figures $2 \mathrm{e}$ and $2 \mathrm{f}$, Foxp3+ cells depicted before and after in vitro generation respectively. On right, figures $2 \mathrm{~g}$ and $2 \mathrm{~h}$ depict CD127 low/- CD4+ CD25+/hi before in vitro generation and in figures $2 \mathrm{i}$ and $2 \mathrm{j}$ same depicted after in vitro generation. 
at three monthly intervals along with viral infection status for HIV, HBsAg and HCV by ELISA and BK polyoma virus by urine cytology for decoy cells. DSA testing was planned every 3 months by qualitative technique. Tregs was measured in peripheral blood of patients of all groups using CD127 mAb (PerCP-Cy), CD4 mAb (phycoerythrin [PE]), CD25 mAb (fluorescein isothiocyanate [FITC]) and CD152 $\mathrm{m}$-allophecocyanin [APC] (BD Biosciences, USA) according to manufacturer's protocol.

\section{Immunosuppression monitoring}

For group-1 and group-2, Tacrolimus, $0.06 \mathrm{mg} / \mathrm{kg}$ body weight (BW)/ day was administered with Prednisone, $20 \mathrm{mg} / \mathrm{day}$. After 6 months posttransplant, Tacrolimus was replaced by Sirolimus, $1 \mathrm{mg} /$ day or mycofenolate sodium, $360 \mathrm{mg}$, twice a day. Prednisone was tapered to $5-10 \mathrm{mg} /$ day by the end of 1 month posttransplant.

Group-3 patients were maintained on standard triple immunosuppression of Tacrolimus, $0.08 \mathrm{mg} / \mathrm{kgBW} /$ day switched to Sirolimus, $2 \mathrm{mg} /$ day at 6 months, Mycofenolate sodium, $720 \mathrm{mg}$, twice a day and Prednisone, $20 \mathrm{mg} /$ day tapered to $10 \mathrm{mg} /$ day by the end of 1 month posttransplant. Tacrolimus levels were measured at weekly intervals for the first month posttransplant, fortnightly for the next 2 months and monthly thereafter (Siemens RxL Max, according to manufacturer's protocol) maintaining trough levels, $4-7 \mathrm{ng} / \mathrm{mL}$. Sirolimus levels were also maintained at same levels as tacrolimus and were measured every month along with urinary proteins to rule out proteinuria. Mycofenolate sodium level measurement was not performed.

Graft biopsy was performed for dysfunction in all groups and managed as per standard guidelines as mentioned in our previous manuscript $[10,11]$. Acute B-cell mediated rejections were treated with one cycle of bortezomib and four plasmapheresis sessions (with $40 \mathrm{ml} / \mathrm{kgBW} / \mathrm{session}$ ), and r-ATG was administered for T-cell mediated rejections which did not respond to methylprednisone. Third immunosuppressant was added in event of failure of recovery. Protocol biopsies were planned after completion of 100 days of stable graft function in a subset of patients of groups 1 and 2 after their informed written consent.

\section{Patient- donor demographics}

All groups were fairly balanced and had 30 patients each with predominant male patients and predominant original disease was unexplained renal failure (Table 1).

\section{Statistical Analysis}

Statistical analysis was performed using Statistical Package for the Social Sciences (SPSS version 20). Data are expressed as mean \pm $\mathrm{SD}$ for continuous variables and numbers for categorical variables. Continuous variables were compared using Student's t test and analysis of variance. Chi square test of Fisher exact test were used to assess the effect of change in differences in categorical variables. Survivals were examined using Kaplan-Meier analysis and compared using the log-rank test for survival analysis between the groups. $\mathrm{P}<0.05$ was considered to be statistically significant.

\section{Results}

No infections/adverse side effects including GVHD were observed in groups 1 and 2. The mean HSC ( $\mathrm{n} \times 10^{8} \mathrm{cells} / \mathrm{kgBW}$ ) generated and infused in group- 1 were $9.62 \pm 5.5$ vs. $12.1 \pm 10.1$ in group- 2 with mean $\mathrm{CD} 34+\left(\mathrm{n} \times 10^{6}\right.$ cells $\left./ \mathrm{kgBW}\right)$ count of $2.7 \pm 2.4$ in group-1 versus $2.2 \pm$ 3.2 in group-2. Mean AD-MSC ( $\mathrm{n} \times 10^{4}$ cells $\left./ \mathrm{kgBW}\right)$ infused were 1.37 \pm 0.5 in group- 1 versus $1.34 \pm 0.6$ in group- 2 . Mean T-regs infused in group-1 were $2.21 \times 10^{4}$ cells $/ \mathrm{kgBW}$ (Table 2).

Over a mean follow-up of $19.34 \pm 4.2$ months in group- 1 and 20.60 \pm 3.67 months in group-2 there was $100 \%$ patient and graft survival. Over a mean follow-up of $20.55 \pm 3.23$ months in group-3 there was $100 \%$ patient and $93.3 \%$ graft survival, depicted in Kaplan Meier analysis $(\mathrm{p}=0.13)$ (Figure 3$)$. One patient lost his graft in group-3 at 3 months posttransplant due to severe acute $\mathrm{T}+\mathrm{B}$ cell mediated rejection which did not respond to treatment and second patient lost his graft to chronic rejection at 8 months posttransplant.

Mean SCr of all groups remained between 1.2 to $1.4 \mathrm{mg} / \mathrm{dL}$. Acute rejection (AR) with Banff score $<\mathrm{ag} 1$ at 1 av 1 ai2 and PTC score 0 was observed in $2(6.7 \%)$ patients of group-1, 3 (10\%) of group-2 and 2 (6.7\%) of group-3. AR with Banff score $\geq$ ag1 at1 av1 ai2 and PTC score $>0$ was observed in $2(6.7 \%)$ patients of group- 2 and $5(16.7 \%)$ of group- 3 . None of the patients of group- 1 and 2 had chronic rejections (CR) whereas 1 patient of group-3 had CR with score $\geq \mathrm{cg} 1 \mathrm{ct} 1 \mathrm{cv} 1 \mathrm{ci} 2$.

All patients of group-1 and 28 (93.3\%) patients of group-2 were on two immunosuppressants; and $2(6.7 \%)$ patients of group-2 required additional Mycofenolate sodium, $360 \mathrm{mg}$ twice a day. Group-3 patients required triple immunosuppression. Protocol biopsy was performed in 3 patients of group- 1 and 3 patients of group- 2 at 1 year posttransplant and all were normal (Figure 4a).

\begin{tabular}{|c|c|c|c|c|}
\hline Demographics & Group-1 & Group-2 & Group-3 & $P$ value \\
\hline Protocol $(n=30)$ & AD-MSC+HSC+Tregs & AD-MSC+HSC & Controls & \\
\hline Male :Female & $24: 6$ & $30: 0$ & $28: 2$ & 0.2 \\
\hline Age (years) & $34.9 \pm 9.45$ & $35.4 \pm 12.5$ & $30.9 \pm 9.7$ & 0.02 \\
\hline $\begin{array}{c}\text { Donors: } \\
\text { Parents/ Spouse/ Sibs/ others }\end{array}$ & $15 / 9 / 5 / 1$ & $11 / 7 / 4 / 8$ & $15 / 10 / 3 / 2$ & 0.6 \\
\hline Donor age (years) & $46.5 \pm 10.1$ & $44.3 \pm 10.1$ & $43.7 \pm 10.4$ & 0.5 \\
\hline $\begin{array}{c}\text { Original disease: } \\
\text { Unexplained / DN/ HTN/ Others }\end{array}$ & $14 / 7 / 5 / 4$ & $15 / 3 / 4 / 8$ & $11 / 0 / 3 / 16$ & 0.5 \\
\hline HLA match & $3.03 \pm 1.3$ & $2.5 \pm 1.35$ & $2.3 \pm 1.21$ & 0.06 \\
\hline \multicolumn{5}{|c|}{ CELL COUNT OF INFUSED CELLS } \\
\hline Mean HSC infused ( $\mathrm{n} \times 10^{8}$ cells $\left./ \mathrm{kgBW}\right)$ & $9.62 \pm 5.5$ & $12.1 \pm 10.1$ & 0 & 0.44 \\
\hline Mean $\mathrm{CD} 34^{+}\left(\mathrm{n} \times 10^{6}\right.$ cells/kgBW $)$ & $2.7 \pm 2.4$ & $2.2 \pm 3.2$ & 0 & 0.23 \\
\hline Mean AD- MSC infused ( $\mathrm{n} \times 10^{4}$ cells/kgBW) & $1.37 \pm 0.5$ & $1.34 \pm 0.6$ & 0 & 0.77 \\
\hline $\begin{array}{l}\text { Mean Tregs infused } \\
\left(\mathrm{n} \times 10^{4} / \mathrm{KgBW}\right)\end{array}$ & 2.21 & 0 & 0 & \\
\hline
\end{tabular}

Table 1: Patient-donor demographics. 
Citation: Trivedi H, Vanikar A, Patel H, Kute V, Dave S (2014) Regulatory T-Cells Support Stem Cell Therapy in Safe Minimization of Immunosuppression in Living Donor Renal Transplantation. J Stem Cell Res Ther 4: 240. doi:10.4172/2157-7633.1000240

Page 5 of 8

\begin{tabular}{|c|c|c|c|c|}
\hline Group (n \pm S.D.) & Group-1 & Group-2 & Group-3 & $P$ value \\
\hline Mean follow-up in months & $19.34 \pm 4.2$ & $20.60 \pm 3.67$ & $20.55 \pm 3.23$ & \\
\hline Patient survival & $100 \%$ & $100 \%$ & $100 \%$ & 1 \\
\hline Graft survival & $100 \%$ & $100 \%$ & $93.3 \%$ & 0.13 \\
\hline \multicolumn{5}{|c|}{ Mean serum creatinine $(\mathrm{mg} / \mathrm{dL})$} \\
\hline 1 month & $1.33 \pm 0.3$ & $1.33 \pm 0.22$ & $1.31 \pm 0.3$ & 0.2 \\
\hline 3 months & $1.32 \pm 0.3$ & $1.33 \pm 0.19$ & $1.22 \pm 0.25$ & 0.21 \\
\hline 6 months & $1.30 \pm 0.33$ & $1.33 \pm 0.28$ & $1.37 \pm 0.56$ & 0.8 \\
\hline 9 months & $1.29 \pm 0.32$ & $1.37 \pm 0.46$ & $1.25 \pm 0.23$ & 0.46 \\
\hline 12 months & $1.29 \pm 0.36$ & $1.36 \pm 0.4$ & $1.24 \pm 0.27$ & 0.40 \\
\hline 15 months & $1.15 \pm 0.29$ & $1.28 \pm 0.21$ & $1.27 \pm 0.36$ & 0.49 \\
\hline 18 months & $1.23 \pm 0.32$ & $1.38 \pm 0.26$ & $1.2 \pm 0.25$ & 0.25 \\
\hline \multicolumn{5}{|l|}{ Biopsy } \\
\hline AR $<$ ag1 at 1 av1 ai 2 ptc 0 & 2 & 3 & 2 & 0.85 \\
\hline$\geq$ ag1 at1 av1 ai2 ptc0 & 0 & 2 & 5 & $<0.01$ \\
\hline$\geq \mathrm{cg} 1 \mathrm{ct} 1 \mathrm{cv} 1 \mathrm{ci} 2 \mathrm{ptc} 0$ & 0 & 0 & 1 & 0.36 \\
\hline \multicolumn{5}{|c|}{ Tregs in peripheral blood } \\
\hline 3 months & $3.51 \pm 0.55$ & $3.28 \pm 0.67$ & $1.58 \pm 0.62$ & $<0.01$ \\
\hline 6 months & $3.12 \pm 0.71$ & $2.94 \pm 0.7$ & $1.43 \pm 0.37$ & $<0.01$ \\
\hline 9 months & $3.16 \pm 1.14$ & $2.93 \pm 0.85$ & $1.76 \pm 1.07$ & $<0.01$ \\
\hline 12 months & $3.09 \pm 1.04$ & $2.96 \pm 1.18$ & $1.84 \pm 0.77$ & $<0.01$ \\
\hline 15 months & $3.02 \pm 0.44$ & $2.98 \pm 0.77$ & $1.98 \pm 0.93$ & $<0.01$ \\
\hline 18 months & $3.52 \pm 0.84$ & $3.19 \pm 0.49$ & $2.09 \pm 0.86$ & $<0.01$ \\
\hline Two immunosuppressants & $30(100 \%)$ & $28(93.3 \%)$ & 0 & $<0.01$ \\
\hline Three immunosuppressants & 0 & $02(6.7 \%)$ & $30(100 \%)$ & $<0.01$ \\
\hline
\end{tabular}

Table 2: Follow-up after transplantation.

\section{Kaplan Meier Analysis Of Graft Survival Of Three Groups}

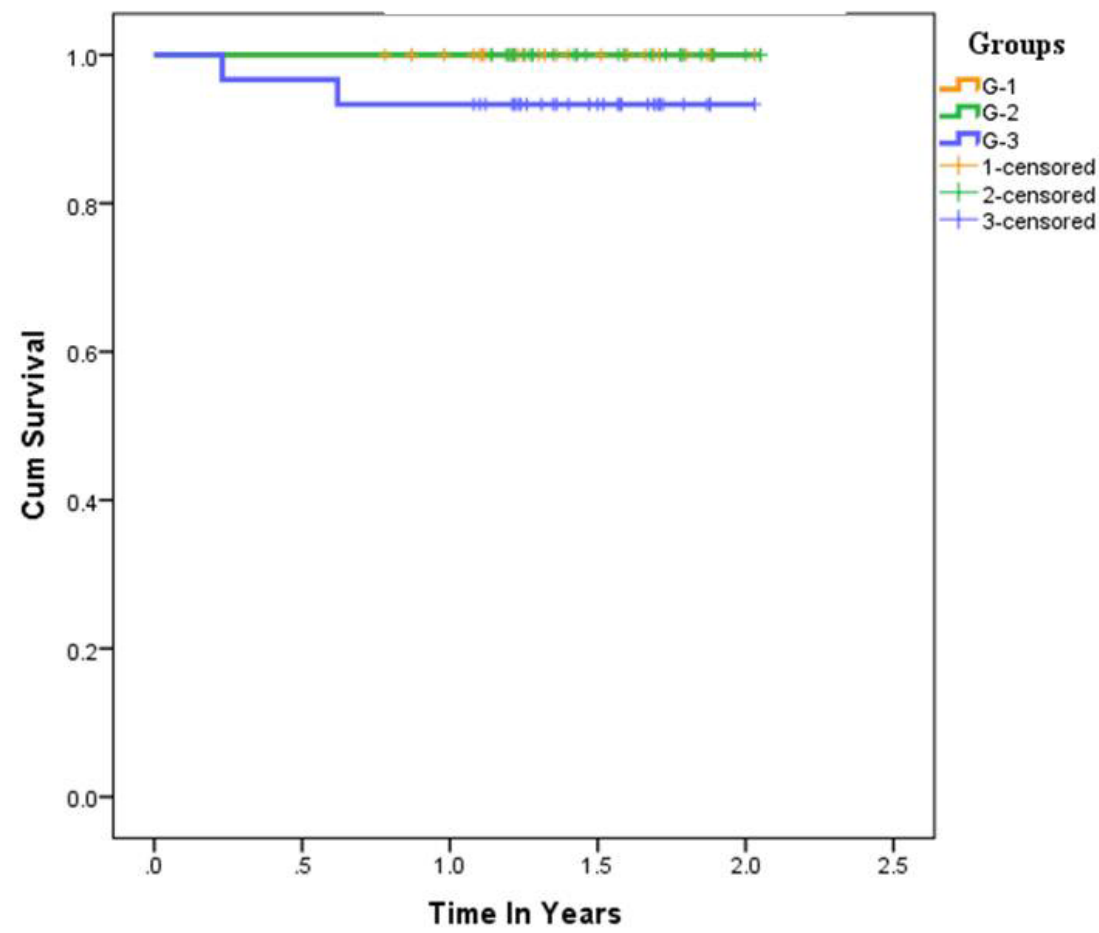

Figure 3: Kaplan Meier Analysis of 3 groups for graft survival.

DSA was tested in 7 patients of group- 1 and group-2, and 8 patients of group-3 at 1 year posttransplant. DSA class-2 was observed in 1 patient of group-1 while 7 patients had no antibodies. In group-2, 2 patients showed DSA class-1 while 5 had no antibodies. In group-3, 3 patients had DSA class-2 while 5 had no antibodies. However there was no correlation of DSA with graft function in groups 1 and 2. In group-3 out of 3 patients with DSA class-2, 1 patient developed rise in SCr to $1.95 \mathrm{mg} / \mathrm{dL}$ from $1.3 \mathrm{mg} / \mathrm{dL}$ in spite of anti-rejection therapy and triple 
Citation: Trivedi H, Vanikar A, Patel H, Kute V, Dave S (2014) Regulatory T-Cells Support Stem Cell Therapy in Safe Minimization of Immunosuppression in Living Donor Renal Transplantation. J Stem Cell Res Ther 4: 240. doi:10.4172/2157-7633.1000240

immunosuppression, while the other 2 patients have maintained stable graft function with $\mathrm{SCr}$ of $1.3 \mathrm{mg} / \mathrm{dL}$ after anti-rejection therapy.

T-regs were maintained at $3-3.5 \%$ in the entire posttransplant period in group-1, $2.9-3.3 \%$ in group $-2(\mathrm{p}=\mathrm{NS})$, and $1.4-2.1 \%$ in group-3 $(\mathrm{p}<0.01)$.

Mean chimerism at 1 month and 12 months in group-1 was 33.6 $\pm 2.8 \%$ and $22.4 \pm 1.7 \%$ and in group- 2 it was $24.9 \pm 2.5 \%$ and $14.6 \pm$ $0.97 \%$ respectively (Figure $4 \mathrm{~b}$ ). No chimerism was observed in group- 3 $(\mathrm{p}<0.01)$.

\section{Discussion}

Transplantation has become an acceptable option to dialysis for chronic renal failure however the major drawback to its own success is requirement of life-long immunosuppression which often compromises quality of life due to risk of metabolic disorders including diabetes, infections, and malignancy in long-run. The other problems are compliance and prohibitive cost of the care especially where the financial burden lies on the family in a developing country. Since transplantation tolerance (stable graft function on zero immunosuppression, with no rejections while keeping immune system intact) is still far from the reach of transplanters in general, the only practical solution is transplantation with effective immunosuppression minimization while extending the benefits of tolerance.

Owen's observation of naturally occurring chimerism in cattle twins was applied to kidney transplantation by Salvatierra and others $[12,13]$. They found that DST pre-transplant resulted into excellent graft survival in one-haplo-mismatch transplants and even in limited zero-match transplants. The effect of DST was found to last for 4 years. Brennan et al. found that even donor BM infusion with DST helped in improving long term graft survival [14]. They observed that there was no risk of GVHD and that both DST and DBM acted as potential immunomodulators by inducing anergy, stimulation of anti-antiHLA antibodies, providing soluble HLA antigens, suppressor cells and/or veto cell activity, clonal deletion, regulation of cell surface

a)

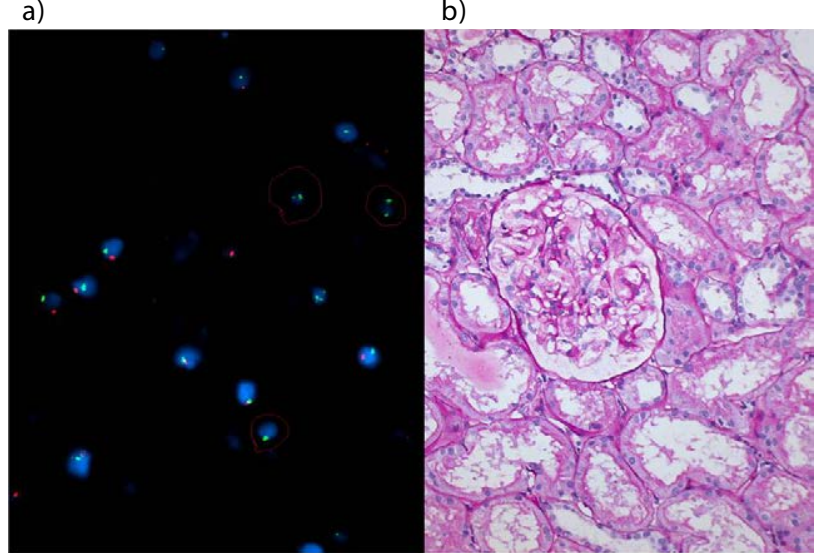

Figure 4: a) On left, peripheral blood lympho-hematopoietic chimerism demonstrated by fluorescent in situ hybridization of the same patient performed on the day of protocol biopsy (cells with 2 green dots depict female cell with $\mathrm{XX}$ chromosomes highlighted by circle, against cells with green and red dots depicting male cell with $\mathrm{X}$ and $\mathrm{Y}$ chromosomes). b On right, Normal protocol biopsy of patient belonging to group-2; 44 years old man underwent renal transplantation for chronic renal failure due to unexplained etiology, with 38 years old wife's kidney (HLA 0/6 match) on $17^{\text {th }}$ August, 2012, biopsy date $2^{\text {nd }}$ August, 2013, immunosuppression: Sirolimus, $1 \mathrm{mg} /$ day and Prednisone, $5 \mathrm{mg} /$ day. Periodic Acid Schiff stain, $x 200$. molecules, regulation of cytokines, promotion of microchimerism, or a combination of these. Out of all, microchimerism with concomitant persistence of soluble donor HLA antigen was believed to be the most effective mechanism for improving graft outcome. Yang et al. carried out rodent studies by infusing single dose of splenocytes from $2 \mathrm{CF}-1$ transgeneic mice expressing a $\mathrm{T}$-cell receptor specifically recognizing Ld, (an MHC-class 1 molecule) into recipient mice followed by skin transplantation [15]. They found that skin grafts lasted long without the need of any immunosuppression and also deleted donor reactive T-cells in periphery of recipient after infusion of DST. There was also significant rise in IL-4 level in sera of mice who received DST.

We have been using DST and HSC since 1998 and we added $\mathrm{AD}-\mathrm{MSC}$ to this combination to improve the graft outcome while minimizing immunosuppression. Our protocols have evolved over the years with enrichment of our experience. We found that PBSC had better outcome than DST since it is rich in regulatory cells [5]. Apart from excellent 1 year patient and graft survival in our study population of more than 1300 patients, we have been able to achieve about $74.7 \%$ graft and $81.8 \%$ patient survival for 5 years with safe minimization of immunosuppression [5]. We added AD-MSC which were generated by indigenously developed techniques, to take the advantage of immunomodulatory, immunosuppressive and tolerogenic properties of MSC tested in skin transplants in baboons and in vitro experiments by Bartholomew et al. and in humans by Aggarwal et al. [16,17]. Our previous experience of using $\mathrm{AD}-\mathrm{MSC}+\mathrm{HSC}$ vs. $\mathrm{HSC}$ alone has also established the benefits of combined use of AD-MSC and HSC in terms of increased survival and sustained decrease in immunosuppression requirement [10].

While using AD-MSC we started observing their long term benefits in the form of control of chronic rejections for which no answer has been found as yet. While searching for the reasons, we found out that MSC generate and recruit Tregs to control proliferation of rejecting cells. Ge et al. have shown that MSCs generate $\mathrm{CD} 4^{+} \mathrm{CD} 25^{+} \mathrm{FoxP} 3^{+}$Tregs in vivo in renal allograft recipients and thereby induce tolerance [18]. MSC generate $\mathrm{CD} 4^{+} \mathrm{CD}^{+}$regulatory cells also which inhibit allogeneic lymphocyte proliferation. There are at least two mechanisms by which MSC generate Tregs; direct cell-to-cell contact in which MSC directly act with NK cells, $\mathrm{CD} 4^{+}$cells, dendritic cells, and the other mechanism is through secretion of soluble factors like prostaglandin E2 and tumor growth factor-alpha $[19,20]$. The beneficial role of Tregs was studied by Amirzargar et al. in 57 renal allograft recipients with stable graft function for 6 months posttransplant [21]. $\mathrm{CD} 4^{+} \mathrm{CD} 25^{+} \mathrm{FoxP} 3^{+}$and CD8 ${ }^{+} \mathrm{CD} 28$ - Tregs, myeloid dendritic cells type 1 and type 2 , and plasmacytoid dendritic cells of these patients were measured pretransplant, and at 2 weeks, 1,3 , and 6 months after transplantation. They observed that mean Tregs decreased 2 weeks post-transplantation and then increased subsequently within 2 months of transplantation. The frequency at 3 months could predict the frequency at 6 months posttransplant. Thus they concluded that Tregs could be considered as potential non-invasive biomarkers for stable graft function.

The most potent mechanisms by which Tregs exert their tolerogenic effects on the grafts are through the phenomenon of "linked suppression" and "infectious tolerance" [22-25]. Tregs produce huge amounts of immune suppressive cytokines like TGF-alpha, IL10 and IL-35, which are known to inhibit a wide spectrum of cellular activities. Through these cytokines Tregs block the cytotoxic effects of Th1 cells and neighbouring cells by direct interaction of the epitopes. This phenomenon is described as "linked suppression". In addition they convert the cytotoxic properties of rejecting cells into regulatory cells through the process of demethylation. This phenomenon is called 
Citation: Trivedi H, Vanikar A, Patel H, Kute V, Dave S (2014) Regulatory T-Cells Support Stem Cell Therapy in Safe Minimization of Immunosuppression in Living Donor Renal Transplantation. J Stem Cell Res Ther 4: 240. doi:10.4172/2157-7633.1000240

Page 7 of 8

"infectious tolerance". Thus although the life of T-cells including Tregs is finite, the phenomena of "infectious tolerance" and "linked suppression" have immortalized the tolerogenicity of Tregs.

This prompted us to generate Tregs in vitro and subsequently use them in clinic. There are mainly two kinds of Tregs; the Induced Tregulatory cells (iTregs) and naturally occurring Tregs (nTregs), both are identified as $\mathrm{CD}^{+} \mathrm{CD} 25^{+} \mathrm{Foxp}^{+\cdot}$ However there is one major difference between them, iTregs develop from mature CD4 ${ }^{+} \mathrm{T}$-cells outside the thymus, whereas nTregs mature within the thymus [25-28]. Both iTregs and nTregs share a similar function including tolerance induction and maintenance, however iTregs have recently been shown to be essential to support and supplement nTregs, in part by expanding TCR diversity within regulatory responses. Epigenetic differences have been observed between nTreg and iTregs, with the former having more stable Foxp3 expression and wider demethylation as compared to iTregs $[27,28]$.

The present study has several unique features. To our knowledge although attempts to induce transplant tolerance have been made by different ways, this is the only study which has shown in vitro generation of different kinds of SC and Tregs and has used them in LDRT in combination with conditioning regimes/ induction therapies. The results in terms of safety, cost and efficacy are encouraging [2939]. Total cost of transplantation including SC and Treg generation is about USD 5500 compared to standard transplantation costing about USD 5000 in our center. Posttransplant care is about USD 50 per month vs. USD 200 per month in standard transplantation and one event of infection incurs an additional budget of minimum USD 500. Noncompliance is also eliminated here. We use non-myeloablative conditioning to create space for grafting of stem cells in addition to deletion of rejecting cells $[40,41]$. We believe that both central and peripheral tolerance are mandatory, hence we infused cells in portal and thymic circulation [42-47]. We have observed sustained chimerism in patients subjected to cell therapy. However we are not able to decipher its effect on graft function since in our past experience we have not found any correlation between chimerism and tolerance.

\section{Conclusion}

Tregs support SCT in safe minimization of immunosuppression in LDRT and opens the gateway to tolerance. This study will also establish proper place of cell therapy in the field of organ transplantation.

\section{Acknowledgments}

The authors thank Dr. P.R.Modi, Dr. SJ Rizvi and their surgical team members, Prof. V.R.Shah and members of Anesthesia and Critical Care unit for clinical support, Dr. Manish Rawal, vascular surgeon for cell infusion and the lab staff of IKDRC-ITS, India, for all the technical help. The authors also thank Priyadarshini Shah for maintaining and providing the data on all the patient charts, follow-up, and Paresh Dhamecha for carrying out statistical analysis.

\section{References}

1. Leventhal J, Abecassis M, Miller J, Gallon L, Ravindra K, et al. (2012) Chimerism and tolerance without GVHD or engraftment syndrome in HLAmismatched combined kidney and hematopoietic stem cell transplantation. Sci Transl Med 4: 124ra28. [PubMed]

2. Kawai $T$, Cosimi $A B$, Spitzer TR, Tolkoff-Rubin $N$, Suthanthiran $M$, et al. (2008) HLA-mismatched renal transplantation without maintenance immunosuppression. N Engl J Med 358: 353-361. [PubMed]

3. Kirk AD, Mannon RB, Kleiner DE, Swanson JS, Kampen RL, et al. (2005) Results from a human renal allograft tolerance trial evaluating T-cell depletion with alemtuzumab combined with deoxyspergualin. Transplantation 80: 10511059. [PubMed]

4. Scandling JD, Busque S, Shizuru JA, Engleman EG, Strober S (2011) Induced immune tolerance for kidney transplantation. N Engl J Med 365: 1359-1360. [PubMed]

5. Vanikar AV, Goplani KR, Feroz A, Kanodia KV, Patel RD, et al. (2011) Operational tolerance in living-related renal transplantation: a single-center experience. Transplant Proc 43: 1551-1558. [PubMed]

6. Takahashi T, Kuniyasu Y, Toda M, Sakaguchi N, Itoh M, et al. (1998) Immunologic self-tolerance maintained by CD25+CD4+ naturally anergic and suppressive T cells: induction of autoimmune disease by breaking their anergic/ suppressive state. Int Immunol 10: 1969-1980. [PubMed]

7. Nikoueinejad H, Amirzargar A1, Sarrafnejad A, Einollahi B, Nafar M, et al. (2014) Dynamic changes of regulatory T cell and dendritic cell subsets in stable kidney transplant patients: a prospective analysis. Iran J Kidney Dis 8: 130-138. [PubMed]

8. Bouvy AP, Klepper M, Kho MM, Boer K, Betjes MG, et al. (2014) The impact of induction therapy on the homeostasis and function of regulatory $T$ cells in kidney transplant patients. Nephrol Dial Transplant 29: 1587-1597. [PubMed]

9. Nguyen MT, Fryml E, Sahakian SK, Liu S, Michel RP, et al. (2014) Pretransplantation Recipient Regulatory T cell Suppressive Function Predicts Delayed and Slow Graft Function after Kidney Transplantation. Transplantation. [PubMed]

10. Vanikar AV, Trivedi HL, Feroze A, Kanodia KV, Dave SD, et al. (2011) Effect of co-transplantation of mesenchymal stem cells and hematopoietic stem cells as compared to hematopoietic stem cell transplantation alone in renal transplantation to achieve donor hypo-responsiveness. Int Urol Nephrol 43 225-232. [PubMed]

11. Solez K, Colvin RB, Racusen LC, Haas M, Sis B, et al. (2008) Banff 07 classification of renal allograft pathology: updates and future directions. Am J Transplant 8: 753-760. [PubMed]

12. Owen RD (1945) Immunogenetic Consequences Of Vascular Anastomoses Between Bovine Twins. Science 102: 400-401. [PubMed]

13. Salvatierra O Jr, Melzer J, Potter D, Garovoy M, Vincenti F, et al. (1985) A seven-year experience with donor-specific blood transfusions. Results and considerations for maximum efficacy. Transplantation 40: 654-659. [PubMed]

14. Brennan DC, Mohanakumar T, Flye MW (1995) Donor-specific transfusion and donor bone marrow infusion in renal transplantation tolerance: a review of efficacy and mechanisms. Am J Kidney Dis 26: 701-715. [PubMed]

15. Yang L, Du Temple B, Khan Q, Zhang L (1998) Mechanisms of long-term donorspecific allograft survival induced by pretransplant infusion of lymphocytes. Blood 91: 324-330. [PubMed]

16. Bartholomew A, Sturgeon C, Siatskas M, Ferrer K, McIntosh K, et al. (2002) Mesenchymal stem cells suppress lymphocyte proliferation in vitro and prolong skin graft survival in vivo. Exp Hematol 30: 42-48. [PubMed]

17. Aggarwal S, Pittenger MF (2005) Human mesenchymal stem cells modulate allogeneic immune cell responses. Blood 105: 1815-1822. [PubMed]

18. Ge W, Jiang J, Arp J (2010) Regulatory T-cell generation and kidney allograft tolerance induced by mesenchymal stem cells associated with indoleamine 2,3-dioxygenase expression. Transplantation 90:1312. [PubMed]

19. Djouad F, Plence P, Bony C, Tropel P, Apparailly F, et al. (2003) Immunosuppressive effect of mesenchymal stem cells favors tumor growth in allogeneic animals. Blood 102: 3837-3844. [PubMed]

20. English K, Ryan JM, Tobin L, Murphy MJ, Barry FP, et al. (2009) Cell contact, prostaglandin $\mathrm{E}(2)$ and transforming growth factor beta 1 play non-redundant roles in human mesenchymal stem cell induction of CD4+CD25(High) forkhead box P3+ regulatory T cells. Clin Exp Immunol 156: 149-160. [PubMed]

21. Nikoueinejad $H$, Amirzargar A1, Sarrafnejad A, Einollahi B, Nafar M, et al (2014) Dynamic changes of regulatory T cell and dendritic cell subsets in stable kidney transplant patients: a prospective analysis. Iran J Kidney Dis 8: 130-138. [PubMed]

22. Hoyne GF, Jarnicki AG, Thomas WR, Lamb JR (1997) Characterization of the specificity and duration of $T$ cell tolerance to intranasally administered peptides in mice: a role for intramolecular epitope suppression. Int Immunol 9: 11651173. [PubMed]

23. Qin S, Cobbold SP, Pope H, Elliott J, Kioussis D, et al. (1993) "Infectious" transplantation tolerance. Science 259: 974-977. [PubMed]

24. Hoyne GF, Dallman MJ, Lamb JR (2000) T-cell regulation of periphera 
Citation: Trivedi H, Vanikar A, Patel H, Kute V, Dave S (2014) Regulatory T-Cells Support Stem Cell Therapy in Safe Minimization of Immunosuppression in Living Donor Renal Transplantation. J Stem Cell Res Ther 4: 240. doi:10.4172/2157-7633.1000240

tolerance and immunity: the potential role for Notch signalling. Immunology 100: 281-288. [PubMed]

25. Lal G, Bromberg JS (2009) Epigenetic mechanisms of regulation of Foxp3 expression. Blood 114: 3727-3735. [PubMed]

26. Marson A, Kretschmer K, Frampton GM, Jacobsen ES, Polansky JK, et al (2007) Foxp3 occupancy and regulation of key target genes during T-cell stimulation. Nature 445: 931-935. [PubMed]

27. Wieczorek G, Asemissen A, Model F, Turbachova I, Floess S, et al. (2009) Quantitative DNA methylation analysis of FOXP3 as a new method for counting regulatory T cells in peripheral blood and solid tissue. Cancer Res 69: 599-608. [PubMed]

28. Haribhai D, Williams JB, Jia S, Nickerson D, Schmitt EG, et al. (2011) A requisite role for induced regulatory $T$ cells in tolerance based on expanding antigen receptor diversity. Immunity 35: 109-122. [PubMed]

29. Salama AD, Womer KL, Sayegh MH (2007) Clinical transplantation tolerance: many rivers to cross. J Immunol 178: 5419-5423. [PubMed]

30. Matthews JB, Ramos E, Bluestone JA (2003) Clinical trials of transplan tolerance: slow but steady progress. Am J Transplant 3: 794-803. [PubMed]

31. Mazariegos GV, Reyes J, Marino IR, Demetris AJ, Flynn B, et al. (1997) Weaning of immunosuppression in liver transplant recipients. Transplantation 63: 243-249. [PubMed]

32. Kawai T, Cosimi AB, Spitzer TR, Tolkoff-Rubin N, Suthanthiran M, et al. (2008) HLA-mismatched renal transplantation without maintenance immunosuppression. N Engl J Med 358: 353-361. [PubMed]

33. Scandling JD, Busque S, Dejbakhsh-Jones S, Benike C, Sarwal M, et al. (2012) Tolerance and withdrawal of immunosuppressive drugs in patients given kidney and hematopoietic cell transplants. Am J Transplant 12: 1133-1145. [PubMed]

34. Leventhal J, Abecassis M, Miller J, Gallon L, Ravindra K, et al. (2012) Chimerism and tolerance without GVHD or engraftment syndrome in HLAmismatched combined kidney and hematopoietic stem cell transplantation. Sci Transl Med 4: 124ra28. [PubMed]

35. Trivedi HL, Kaneku H, Terasaki PI, Feroz A, Vanikar AV, et al. (2009) Clonal deletion using total lymphoid irradiation with no maintenance immunosuppression in renal allograft recipients. Clin Transpl. [PubMed]
36. Trivedi HL, Terasaki PI, Feroz A, Vanikar AV, Trivedi VB, et al. (2010) Clonal deletion with bortezomib followed by low or no maintenance immunosuppression in renal allograft recipients. Transplantation 90: 221-222. [PubMed]

37. Scandling JD, Busque S, Shizuru JA, Engleman EG, Strober S (2011) Induced immune tolerance for kidney transplantation. N Engl J Med 365: 1359-1360. [PubMed]

38. Leventhal J, Abecassis M, Miller J (2013) Tolerance induction in HLA disparate living donor kidney transplantation by donor stem cell infusion: durable chimerism predicts outcome. Transplantation 95: 169. [PubMed]

39. Kirk AD, Mannon RB, Kleiner DE (2005) Results from a human renal allograft tolerance trial evaluating T-cell depletion with alemtuzumab combined with deoxyspergualin. Transplantation 80: 1051. [PubMed]

40. Slavin S, Fuks Z, Kaplan HS, Strober S (1978) Transplantation of allogeneic bone marrow without graft-versus-host disease using total lymphoid irradiation. J Exp Med 147: 963-972. [PubMed]

41. Slavin S, Gottlieb M, Strober S, Bieber C, Hoppe R, et al. (1979) Transplantation of bone marrow in outbred dogs without graft-versus-host disease using total lymphoid irradiation. Transplantation 27: 139-142. [PubMed]

42. Blanco B, Pérez-Simón JA, Sánchez-Abarca LI, Caballero-Velazquez $T$ Gutierrez-Cossío S, et al. (2009) Treatment with bortezomib of human CD4+ T cells preserves natural regulatory $T$ cells and allows the emergence of a distinct suppressor T-cell population. Haematologica 94: 975-983. [PubMed]

43. Page EK, Dar WA, Knechtle SJ (2012) Tolerogenic therapies in transplantation. Front Immunol 3: 198. [PubMed]

44. Remuzzi G, Perico N, Carpenter CB, Sayegh MH (1995) The thymic way to transplantation tolerance. J Am Soc Nephrol 5: 1639-1646. [PubMed]

45. Posselt AM, Barker CF, Tomaszewski JE, Markmann JF, Choti MA, et al. (1990) Induction of donor-specific unresponsiveness by intrathymic islet transplantation. Science 249: 1293-1295. [PubMed]

46. Turvey SE, Fry JW, Wood KJ (1999) New insights on the mechanisms of acquired intrathymic tolerance. Curr Opin Organ Transplant 4: 50. [PubMed]

47. Wu SL, Pan CE (2013) Tolerance and chimerism and allogeneic bone marrow/ stem cell transplantation in liver transplantation. World J Gastroenterol 19: 5981-5987. [PubMed] 